\title{
PENERAPAN PERLINDUNGAN HUKUM TERHADAP WISATAWAN YANG MENGALAMI KERUGIAN DI OBYEK WISATA (STUDI DI KABUPATEN PURBALINGGA)*
}

\author{
Sarsiti dan Muhammad Taufiq \\ Fakultas Hukum Universitas J enderal Soedirman Purwokerto
}

\begin{abstract}
In the era of globalization, the protection of domestic service users and the entreprenuer of domestic tourism is needed. This research concern about the application of legal protection and remedies law for tourist who suffered losses in tourist location. The method used is normative juridical approach. The collection of legal substance done by documentary and then analyzed using method of normative qualitative. Based on this research, the Local Government of Purbalingga have no consider the consumer, as a subject in the tourism industry, because only one tourist location existing regulations, and it was only regulate the formation of regional companies. Application of compensation is only applied to physical accident at the tourist location in, cooperation with PT J asa Raharja, whereas the loss of non physical/material not regulated yet. Dispute settlement as a result of suffered losses in the tourist location can be done peacefully or adversarially by using BPSK or filling a lawsuit to court.
\end{abstract}

Keywords: legal protection, tourist, losses

\begin{abstract}
Abstrak
Pada era globalisasi, perlindungan terhadap pengguna jasa domestik dan para mengusaha pariwisata domestik diperlukan. Tulisan ini membahas mengenai penerapan perlindungan hukum terhadap wisatawan dan upaya hukum bagi wisatawan yang menderita kerugian di obyek wisata. Metode yang digunakan adalah metode pendekatan yuridis normatif. Pengumpulan bahan hukum dilakukan melalui metode kepustakaan dan selanjutnya dianalisis dengan menggunakan metode normatif kualitatif. Berdasarkan hasil penelitian, Pemerintah Daerah Kabupaten Purbalingga belum menempatkan konsumen, sebagai subjek dalam industri kepariwisataan, karena hanya satu obyek wisata yang sudah ada regulasinya, itu pun hanya mengatur mengenai pembentukan perusahaan daerah. Penerapan ganti kerugian hanya diberlakukan terhadap kecelakaan fisik di obyek wisata dilakukan melalui kerjasama Perusahaan Daerah dengan PT J asa Raharja, sedangkan kerugian non fisik/ materiil belum terdapat pengaturannya. Penyelesaian sengketa sebagai akibat dirugikannya wisatawan di obyek wisata dapat dilakukan secara damai maupun secara adversarial melalui BPSK maupun pengajuan gugatan ke pengadilan.
\end{abstract}

Kata kunci: perlindungan hukum, wisatawan, kerugian

\section{Pendahuluan}

Konsekuensi suatu negara hukum adalah menempatkan hukum di atas segala kehidupan bernegara dan bermasyarakat. Negara dan masyarakat diatur dan diperintah oleh hukum, bukan diperintah oleh manusia. Hukum berada di

- Tulisan ini merupakan hasil Penelitian Pemula yang dilaksanakan berdasarkan Surat Perjanjian Pelaksanaan J asa Penelitian Tahun Anggaran 2011 Nomor: 4323.36/ H23.9/ PN/ 2011. Ucapan terima kasih disampaikan kepada Okiawan Waseso, Mahasiswa FH UNSOED, yang telah membantu pelaksanaan penelitian ini. atas segalanya, kekuasaan dan penguasa tunduk kepada hukum. Hubungan yang menimbulkan hak dan kewajiban telah diatur dalam peraturan hukum disebut hubungan hukum.

Hukum harus mampu mengintegrasikan berbagai kepentingan, sehingga benturan kepentingan itu dapat ditekan sekecil mungkin. Perlindungan terhadap suatu kepentingan tertentu, dapat dilakukan dengan cara membatasi kepentingan pihak lain. Perlindungan hukum bagi setiap Warga Negara Indonesia tanpa ter- 
kecuali, dapat ditemukan dalam UUD 1945. Setiap produk yang dihasilkan oleh legislatif harus senantiasa mampu memberikan jaminan perlindungan hukum bagi semua orang, bahkan harus mampu menangkap aspirasi-aspirasi hukum dan keadilan yang berkembang di masyarakat. Menurut Hetty Hasanah, perlindungan hukum merupakan segala upaya yang dapat menjamin adanya kepastian hukum, sehingga dapat memberikan perlindungan hukum kepada pihak-pihak yang bersangkutan atau yang melakukan tindakan hukum, ${ }^{1}$ Di era reformasi tuntutan perlindungan dan jaminan hak asasi manusia semakin mengedepan. Hal tersebut berkaitan dengan kekuasaan, kekuatan sosial, dan struktur sosial yang ada. Sebagai negara demokrasi, dimana kedaulatan ada di tangan rakyat, partisipasi rakyat sangat diperlukan. Rakyatlah sebagai penentu terwujudnya jaminan pelaksanaan perlindungan hak asasi ini. ${ }^{2}$

Perlindungan terhadap potensi wisata yang ada harus dapat dipertahankan, karena obyek wisata merupakan ciri khas suatu negara. Pengembangan faktor penunjang dalam mengembangkan industri pariwisata Indonesia juga harus diperhatikan dan di jaga eksistensinya, sehingga dalam percaturan industri kepariwasatan, Indonesia dapat bersaing.

Pariwisata merupakan sebuah industri yang unik dan memiliki ciri khas, yaitu nilainilai tradisi budaya dan obyek-obyek pariwisata yang khas/unik. Dalam lingkup nasional, sektor pariwisata dianggap sebagai sektor yang potensial dimasa yang akan datang. Menurut analisis World Travel and Tourism Council (WTTC), industri pariwisata menyumbang $9,1 \%$ dari produk domestik bruto (PDB) Indonesia. ${ }^{3} \mathrm{Hal}$ harus disikapi oleh pemerintah daerah di Indonesia untuk meningkatkan potensi wisata untuk dapat dija-dikan sebagai sarana guna meningkatkan

1 Hetty Hasanah, "Perlindungan Konsumen dalam Perjanjian Pembiayaan Konsumen atas Kendaraan Bermotor dengan Fidusia", J urnal Unikom, Vol 3 Tahun 2004, diakses pada web site: http//jurnal. unikom.ac.id/vol3/ perlindungan.html., hlm. 1.

2 Suparman Khan, "Apresiasi hak asasi manusia dalam rangka demokratisasi di Indonesia", J urnal J urisprudentia Vol. 1 No. 1 I Tahun 2001, hlm. 95

3 Oka A Yoety, 2009, Industri Pariwisata dan Peluang Kesempatan Kerja. J akarta: PT Pertja, hlm. 1 pendapatan asli daerah. Sumber pendapatan asli daerah sendiri merupakan sumber keuangan daerah yang digali dari dalam wilayah daerah yang bersangkutan yang dapat berupa hasil pajak daerah, hasil retribusi daerah, hasil pengelolaan kekayaan daerah. Berlakunya undang-undang otonomi daerah mengakibatkan pemerintah daerah dituntut untuk menggali sumber pendapatan asli daerah, karena tidak mungkin terus menggantungkan bantuan dari pusat saja untuk membiayai pembangunan. ${ }^{4}$ Pada era otonomi daerah, pemerintah daerah memiliki otonomi penuh mengurus urusan rumah tangganya sendiri. Urusan yang tetap menjadi wewenang penuh pemerintah pusat meliputi urusan keimigrasian, moneter, pertahanan, keamanan, peradilan dan sebagian pendidikan masih ditangan pemerintah pusat, meskipun pelaksanaannya oleh pemerintah daerah.

Proses pengembangan pariwisata tidak terlepas dari kemampuan daerah dalam mengelola potensi yang ada, yang didukung oleh pengetahuan dan keterampilan sumber daya manusia yang ada, serta peran serta masyarakat dalam iklim keterbukaan dan demokratisasi. Penerapan otonomi daerah mengakibatkan pengembangan industri pariwisata yang meliputi pembiayaan, perizinan, perencanaan dan evaluasi menjadi kewenangan pemerintah daerah untuk menyelenggarakannya. Daerah dituntut lebih mandiri dalam mengembangkan obyek dan potensi wisatanya. Perlindungan terhadap pengguna jasa domestik dan para pengusaha pariwisata domestik sangat diperlukan, sehingga industri kepariwisataan terlindungi. Otonomi daerah harus memacu daerah menggali potensi yang ada di daerah, serta menjamin terwujudnya pembangunan daerah yang berkelanj utan.

Berkaitan dengan kepariwisataan, telah hadir Undang-undang No. 10 Tahun 2009 tentang Kepariwisataan (selan-jutnya disingkat UU Kepariwisataan). Undang-undang ini dilatarbelakangi: pertama, keadaan alam, flora, dan fauna, sebagai karunia Tuhan Yang Maha Esa, serta peninggalan purbakala, peninggalan se-

Hadion Wijoyo, "Problematika Hukum di Bidang Investa-si dalam Era Otonomi Daerah". Jurnal Hukum Respublica, Vol. 5, No. 2, Tahun 2006, hlm. 162 
jarah, seni, dan budaya yang dimiliki bangsa Indonesia merupakan sumber daya dan modal pembangunan kepariwisataan untuk peningkatan kemakmuran dan kesejahteraan rakyat sebagaimana terkandung dalam Pancasila dan Pembukaan UUD 1945; kedua, kebebasan melakukan perjalanan dan memanfaatkan waktu luang dalam wujud berwisata merupakan bagian dari hak asasi manusia; ketiga, kepariwisataan merupakan bagian integral dari pembangunan nasional yang dilakukan secara sistematis, terencana, terpadu, berkelanjutan, dan bertanggung jawab dengan tetap memberikan perlindungan terhadap nilai-nilai agama, budaya yang hidup dalam masyarakat, kelestarian dan mutu lingkungan hidup, serta kepentingan nasional; dan keempat, pembangunan kepariwisataan diperlukan untuk mendorong pemerataan kesempatan berusaha dan memperoleh manfaat serta mampu menghadapi tantangan perubahan kehidupan lokal, nasional, dan global. UU No. 10 Tahun 2009 ini telah menghapuskan UU No. 9 Tahun 1990 yang tidak sesuai lagi dengan tuntutan dan perkembangan kepariwisataan sehingga perlu diganti.

Wisata dalam undang-undang ini diartikan sebagai kegiatan perjalanan yang dilakukan oleh seseorang atau sekelompok orang dengan mengunjungi tempat tertentu untuk tujuan rekreasi, pengembangan pribadi, atau mempelajari keunikan daya tarik wisata yang dikunjungi dalam jangka waktu sementara (Pasal 1 ayat (1) UU No. 10 Tahun 2009). Pariwisata adalah berbagai macam kegiatan wisata dan didukung berbagai fasilitas serta layanan yang disediakan oleh masyarakat, pengusaha, Pemerintah, dan Pemerintah Daerah (Pasal 1 ayat (3) UU No. 10 Tahun 2009). Orang yang melakukan wisata kemudian disebut sebagai wisatawan.

Kepariwisataan diselenggarakan dengan mendasarkan pada prinsip-prinsip: pertama, menjunjung tinggi norma agama dan nilai budaya sebagai pengejawantahan dari konsep hidup dalam keseimbangan hubungan antara manusia dan Tuhan Yang Maha Esa, hubungan antara manusia dan sesama manusia, dan hubungan antara manusia dan lingkungan; kedua, menjunjung tinggi hak asasi manusia, keraga- man budaya, dan kearifan lokal; ketiga, memberi manfaat untuk kesejahteraan rakyat, keadilan, kesetaraan, dan proporsionalitas; keempat, memelihara kelestarian alam dan lingkungan hidup; kelima, memberdayakan masyarakat setempat; kelima, menjamin keterpaduan antarsektor, antardaerah, antara pusat dan daerah yang merupakan satu kesatuan sistemik dalam kerangka otonomi daerah, serta keterpaduan antarpemangku kepentingan; keenam, mematuhi kode etik kepariwisataan dunia dan ke-sepakatan internasional dalam bidang pariwisata; dan ketujuh, memperkukuh keutuhan Negara Kesatuan Republik Indonesia.

Undang-undang Kepariwisataan mengatur hak dan kewajiban wisatawan dan pengelola/ pengusaha wisata. Wisatawan berhak untuk memperoleh: informasi yang akurat mengenai daya tarik wisata; pelayanan kepariwisataan sesuai dengan standar; perlindungan hukum dan keamanan; pelayanan kesehatan; perlindungan hak pribadi; dan perlindungan asuransi untuk kegiatan pariwisata yang berisiko tinggi (Pasal 20), selain itu wisatawan yang memiliki keterbatasan fisik, anak-anak, dan lanjut usia berhak mendapatkan fasilitas khusus sesuai dengan kebutuhannya (Pasal 21). Kewajiban dari wisatawan meliputi: menjaga dan menghormati norma agama, adat istiadat, budaya, dan nilainilai yang hidup dalam masya-rakat setempat; memelihara dan melestarikan lingkungan; turut serta menjaga ketertiban dan keamanan lingkungan; dan turut serta mencegah segala bentuk perbuatan yang melanggar kesusilaan dan kegiatan yang melanggar hukum (Pasal 25).

Pengelola/ Pengusaha Pariwisata sendiri mempunyai hak: mendapatkan kesempatan yang sama dalam berusaha di bidang kepariwisataan; membentuk dan menjadi anggota asosiasi kepariwisataan; mendapatkan perlindungan hukum dalam berusaha; dan mendapatkan fasilitas sesuai dengan ketentuan peraturan perundang-undangan (Pasal 22), sedangkan kewajibannya meliputi: menjaga dan menghormati norma agama, adat istiadat, budaya, dan nilai-nilai yang hidup dalam masyarakat setempat; memberikan informasi yang akurat dan bertanggung jawab; memberikan pelayanan 
yang tidak diskriminatif; memberikan kenyamanan, keramahan, perlindungan keamanan, dan keselamatan wisatawan; memberikan perlindungan asuransi pada usaha pariwisata dengan kegiatan yang berisiko tinggi; mengembangkan kemitraan dengan usaha mikro, kecil, dan koperasi setempat yang saling memerlukan, memperkuat, dan menguntungkan; mengutamakan penggunaan produk masyarakat setempat, produk dalam negeri, dan memberikan kesempatan kepada tenaga kerja lokal; meningkatkan kompetensi tenaga kerja melalui pelatihan dan pendidikan; berperan aktif dalam upaya pengembangan prasarana dan program pemberdayaan masyarakat; turut serta mencegah segala bentuk perbuatan yang melanggar kesusilaan dan kegiatan yang melanggar hukum di lingkungan tempat usahanya; memelihara lingkungan yang sehat, bersih, dan asri; memelihara kelestarian lingkungan alam dan budaya; menjaga citra negara dan bangsa Indonesia meIalui kegiatan usaha kepariwisataan secara bertanggung jawab; dan menerapkan standar usaha dan standar kompetensi sesuai dengan ketentuan peraturan perundangan ( $\mathrm{Pa}-\mathrm{sal} 26)$.

Beberapa musibah yang terjadi di obyek wisata cenderung selalu dibebankan kepada wisatawan, dengan asumsi karena kekalaian wisatawannya sendiri, seperti hanyutnya wisatawan di obyek wisata pantai, cidera atau meninggalnya pendaki di gunung dan lain sebagainya. Beberapa waktu yang lalu, kita dikejutkan dengan tewasnya wisatawan saat mencoba beberapa area permainan seperti tewasnya Riska Putri Yulianti (7), warga Kelurahan Mekarjaya, Sukmajaya, Kota Depok, Jawa Barat, akibat terjatuh dari flying fox. ${ }^{5}$ Sebelumnya, kecelakaan serupa yang menewaskan korban juga terjadi di Taman Wisata Candi Borobudur, Magelang, Jawa Tengah, pada 24 J uni 2010 Ialu. Korban ber-nama Budi Rahayu (42) tewas seketika usai mencoba flying fox, dan terjatuh setelah tali yang membentang dengan ketinggian 12 meter putus. Kecelakaan serupa terjadi di per-

Endang Gunawan, Kecelakaan Flying Fox, Taman Matahari, Selasa, 7 J uni 2011 19:14 wib, http:// news.oke zone.com/ read/ 2011/ 06/ 07/ 338/ 465628/ kecelakaanflying-fox-taman-matahari, diakses pada tanggal $11 \mathrm{~J} \mathrm{u}$ ni 2011 mainan flying fox di Hotel Sindang Reret, Lembang, Jawa Barat, pada 31 Desember 2010 lalu. Korban seorang bocah laki-laki mengalami patah tulang sikut karena bermain flying fox, sehingga harus dioperasi beberapa kali.

Kabupaten Purbalingga sendiri, merupakan kabupaten yang sedang giat-giatnya membangun melalui konsep investasi. Investasi di wilayah Kabupaten Purbalingga, selain investasi di bidang industri, juga sedang menata pembangunan obyek wisatanya. J ulukan magnet wisata J awa Tengah memang pantas disandang Kabupaten Purbalingga. Letaknya di kaki Gunung Slamet, sehingga hawanya sejuk dan pemandangan perbukitan yang indah. Kabupaten Purbalingga letaknya sekitar 180 km dari Kota Semarang. Beragam pilihan lokasi wisata bisa dikunjungi, mulai dari Gua Lawa, Owabong, Reptile \& Insect Park, wisata taman Akuarium Raksasa Purbasari Pancuran Mas sampai dengan perkebunan buah naga dan stroberi, semuanya menyaj ikan sensasi wisata yang berbeda.

Daerah Purbalingga tidak memiliki garis pantai, namun Purbalingga mempunyai pantai buatan bernama Pantai Bebas Tsunami. Nama sebuah wahana wisata yang terletak di Obyek Wisata Air Bojongsari atau yang lebih dikenal dengan sebutan Owabong. Obyek wisata Owabong terletak di JI. Raya Owabong, Kecamatan Bojongsari-Purbalingga. Owabong baru diresmikan 18 Maret 2005. Sebagian besar wahana mengetengahkan sarana air, mulai dari Olimpyc Pool yang berupa kolam renang profesional, kolam arus, menikmati gebyuran air di wahana ember tumpah, pesta air, sampai dengan miniatur pantai bebas tsunami. Miniatur pantai ini sangat luas mencapai $1.200 \mathrm{~m}^{2}$ lengkap dengan pasir putih dan gelombang buatan. Fasilitas Waterboom bisa menjadi ajang pacu adrenalin, dengan menaiki spiral waterslide dan torpedo waterslide setinggi $13 \mathrm{~m}$. Sumber airnya sendiri diambil dari mata air alami tanpa kaporit atau penjernih air. Owabong, selain wisata air, juga menyediakan wahana lain seperti sirkuit gokart, menaklukan sirkuit dengan motor besar di arena ATV atau bermain perang medan terbuka di arena Paintball. 
Purbalingga juga memiliki obyek wisata Reptile \& Insect Park. Obyek wisata ini hanya berjarak $2 \mathrm{~km}$ dari Owabong Anda bisa mengunjungi Reptile and Insect Park (museum reptil dan serangga). Area yang popular dengan sebutan taman reptil ini memiliki luas 6 hektar. Taman reptil dibuat terpadu. Suguhan utamanya adalah aneka reptil, seperti ular, iguana, kadal, buaya dan biawak. Koleksi ular hidup yang dipajang sangat lengkap, lebih dari 65 spesies. Diantaranya ular python, king kobra, belang, pucuk hingga kobra albino yang langka. Taman reptil juga menyuguhkan aneka koleksi jenis serangga. Sekitar 841 spesies serangga tertata rapi. Koleksi aneka jenis kupu-kupu juga sangat lengkap dan menjadi daya tarik lain taman reptile.

Obyek wisata lainnya adalah Taman Akuarium Raksasa Purbasari Pancuran Mas. Letaknya di Kecamatan Padamara. Tiket masuknya relatif murah, namun yang disuguhkan sungguh istimewa. Selain beragam koleksi ikan, pengun-jung juga bisa berenang atau melihat aneka jenis burung di Taman Burung. Beragam ikan air tawar menjadi suguhan utama obyek wisata ini. J enis ikan seperti ikan sadat, udang hias, arwana, Ikan Buaya dan beragam jenis Koi. Puluh-an jenis ikan lainnya tertapa rapi di akuarium ukuran besar hingga kecil. Salah satu koleksi Andalan Pancuran Mas adalah koleksi ikan Arapaima Gigas yang panjangnya mencapai 2 meter. Konon ikan ini berasal dari Sungai Amazon. Obyek wisata ini juga terdapat lokasi ta-man burung masih satu area dengan obyek wisata Pancuran Mas. Aneka jenis burung dan unggas terpajang rapi di kandangnya.

Keindahan obyeh wisata, tidaklah selalu menyenangkan bagi wisatawan. Wisatawan kadang kala harus dihadapkan pada suatu kerugian pada tubuh wisatawan, seperti adanya kecelakaan selama berwisata yang mengakibatkan luka, cacat sampai kematian, atau bahkan kerugian pada harta benda wisatawan seperti pencopetan, perampokan atau kehilangan kendaraan di obyek wisata.

Penelitian dalam bidang ini perlu dilakukan, agar pihak-pihak terkait dengan kepariwisataan, khususnya pemerintah daerah, lebih memperhatikan lagi perlindungan hukum terhadap wisatawan, melalui pembentukan kebijakan dalam bidang kepariwisataan, mengingat UU No. 10 Tahun 2009 tentang kepariwisataan cenderung hanya memberikan perlindungan hukum bagi obyek wisatanya itu sendiri.

\section{Perumusan Masalah}

Berdasarkan latar belakang tersebut di atas, penulis tertarik untuk membahas mengenai penerapan perlindungan hukum terhadap wisatawan di obyek wisata Kabupaten Purbalingga dan upaya hukum bagi wisatawan yang menderita kerugian di obyek wisata.

\section{Metode Penelitian}

Tipe penelitian ini adalah yuridis normatif dengan menggunakan beberapa pendekatan masalah yang meliputi pendekatan undangundang (statute approach), pendekatan konseptual (conceptual approach) dan pendekatan kasus (case approach). Bahan hukum yang digunakan meliputi bahan hukum primer, sekunder dan bahan non hukum. Bahan Hukum Primer meliputi: UU No. 10 Tahun 2009 tentang Kepariwisataan; UU No. 8 Tahun 1999 tentang Perlindungan Konsumen; UU No.32 Tahun 2004 Tentang Pemerintahan Daerah; Perda Kabupaten Purbaling-ga No. 38 Tahun 2005 tentang Persahaan Daerah Obyek Wisata Air Bojongsari. Bahan hukum sekunder meliputi hasil penelitian hukum, jurnal-jurnal hukum, kamus-kamus hukum dan bahan non hukum meliputi: bukubuku, hasil penelitian, jurnal ilmiah. Bahan Hukum dikumpulkan dengan menggunakan metode kepustakaan dan metode dokumenter, kemudian dianalisis secara kualitatif.

\section{Pembahasan}

\section{Penerapan Perlindungan Hukum terhadap Wisatawan di Obyek Wisata Kabupaten Purba- lingga}

Berkaitan dengan kepariwisataan, pada tahun 2009 telah disahkan UU No. 10 Tahun 2009 tentang Kepariwisataan (selanjutnya disingkat UU Kepariwisataan). Wisata dalam undang-undang ini diartikan sebagai kegiatan perjalanan yang dilakukan oleh seseorang atau 
sekelompok orang dengan mengunjungi tempat tertentu untuk tujuan rekreasi, pengembangan pribadi, atau mempelajari keunikan daya tarik wisata yang dikunjungi dalam jangka waktu sementara (Pasal 1 ayat (1) UU No. 10 Tahun 2009), sedangkan pariwisata adalah berbagai macam kegiatan wisata dan didukung berbagai fasilitas serta layanan yang disediakan oleh masyarakat, pengusaha, Pemerintah, dan Pemerintah Daerah (Pasal 1 ayat (3) UU No. 10 Tahun 2009). Orang yang melakukan wisata kemudian disebut sebagai wisatawan, sedangkan orang atau sekelompok orang yang melakukan kegiatan usaha pariwisata disebut sebagai pengusaha pariwisata.

Undang-undang Kepariwisataan mengatur hak dan kewajiban wisatawan dan pengelola/ pengusaha wisata. Wisatawan berhak untuk memperoleh: informasi yang akurat mengenai daya tarik wisata; pelayanan kepariwisataan sesuai dengan standar; perlindungan hukum dan keamanan; pelayanan kesehatan; perlindungan hak pribadi; dan perlindungan asuransi untuk kegiatan pariwisata yang berisiko tinggi (Pasal 20), selain itu wisatawan yang memiliki keterbatasan fisik, anak-anak, dan lanjut usia berhak mendapatkan fasilitas khusus sesuai dengan kebutuhannya (Pasal 21). Kewajiban dari wisatawan meliputi: menjaga dan menghormati norma agama, adat istiadat, budaya, dan nilai-nilai yang hidup dalam masyarakat setempat; memelihara dan melestarikan lingkungan; turut serta menjaga ketertiban dan keamanan lingkungan; dan turut serta mencegah segala bentuk perbuatan yang melanggar kesusilaan dan kegiatan yang melanggar hukum (Pasal 25).

Pengelola/ Pengusaha Pariwisata sendiri mempunyai hak mendapatkan kesempatan yang sama dalam berusaha di bidang kepariwisataan; membentuk dan menjadi anggota asosiasi kepariwisataan; mendapatkan perlindungan hukum dalam berusaha; dan mendapatkan fasilitas sesuai dengan ketentuan peraturan perundangundangan (Pasal 22), sedangkan kewajibannya meliputi menjaga dan menghormati norma agama, adat istiadat, budaya, dan nilai-nilai yang hidup dalam masyarakat setempat; memberikan informasi yang akurat dan bertanggung ja- wab; memberikan pelayanan yang tidak diskriminatif; memberikan kenyamanan, keramahan, perlindungan keamanan, dan keselamatan wisatawan; memberikan perlindungan asuransi pada usaha pariwisata dengan kegiatan yang berisiko tinggi; mengembangkan kemitraan dengan usaha mikro, kecil, dan koperasi setempat yang saling memerlukan, memperkuat, dan menguntungkan; mengutamakan penggunaan produk masyarakat setempat, produk dalam negeri, dan memberikan kesempatan kepada tenaga kerja lokal; meningkatkan kompetensi tenaga kerja melalui pelatihan dan pendidikan; berperan aktif dalam upaya pengembangan prasarana dan program pemberdayaan masyarakat; turut serta mencegah segala bentuk perbuatan yang melanggar kesusilaan dan kegiatan yang melanggar hukum di lingkungan tempat usahanya; memelihara lingkungan yang sehat, bersih, dan asri; memelihara kelestarian lingkungan alam dan budaya; menjaga citra negara dan bangsa Indonesia melalui kegiatan usaha kepariwisataan secara bertanggung jawab; dan menerapkan standar usaha dan standar kompetensi sesuai dengan ketentuan peraturan perundangan ( $\mathrm{Pa}$ sal 26).

Pada dasarnya, perlindungan hukum yang diberikan oleh UU Kepariwisataan ini hanya menekankan pada perlindungan terhadap obyek wisata itu sendiri. Hal ini tampak pada keseriusan pemberian sanksi pada Pasal 64 yang mengatur bahwa setiap orang yang dengan sengaja dan melawan hukum merusak fisik daya tarik wisata dipidana dengan pidana penjara paling lama 7 (tujuh) tahun dan denda paling banyak Rp.10.000.000.000,00 (sepuluh miliar rupiah). Sementara itu, pelanggaran terhadap hak-hak wisatawan hanya dikenakan sanksi administratif, mulai dari teguran tertulis, pembatasan kegiatan usaha dan pembekuan sementara kegiatan usaha.

Perlindungan terhadap wisatawan baik wisatawan mancanegara maupun domestik, dengan demikian secara normatif dapat dikatakan masih relatif rendah dan hukum yang berlaku tidak mempunyai kekuatan untuk melindungi wisatawan. Sampai saat ini para wisatawan cenderung hanya menjadi obyek oleh pelaku 
bisnis pariwisata yang tidak bertanggung jawab. Hal ini menjadi perhatian penting, bahwa sangat diperlukan sebuah peraturan yang tidak hanya membahas tentang kepariwisataan, tetapi juga perlindungan terhadap para wisatawan dari segala hal baik menyangkut aspek perjalanan, penginapan, obyek obyek atau tujuan wisata dan pengaturan hak dan kewajiban wisatawan. Selain itu, untuk menghindari ketidakpastian hukum, sifat ego sektoral baik di tingkat departemen/ kementerian maupun pemerintah daerah, harus dihilangkan, sehingga terwujud sinkronisasi peraturan perundangan. ${ }^{6}$

Proses pengembangan pariwisata tidak terlepas dari kemampuan daerah dalam mengeIola potensi yang ada dan ini juga didukung oleh pengetahuan dan keterampilan sumber daya manusia yang ada serta peran serta masyarakat dalam iklim keterbukaan dan demokratisasi, dan juga menyadari sebebearpa penting pariwisata dapat mempengaruhi perkembangan sebuah daerah, daerah dari daerah yang miskin menjadi daerah yang maju dan berkembang. Pemberian kewenangan kepada pemerintah daerah merupakan wujud pelaksanaan dari otonomi daerah. Undang-Undang No.32 Tahun 2004 Tentang Pemerintahan Daerah menganut prinsip otonomi secara luas, nyata dan bertanggung jawab. Hal ini berarti daerah diberikan kewenangan untuk mengatur dan mengurus urusan pmerintahan di luar urusan pemerintahan pusat yang telah ditetapkan undang-undang. Penyelenggaraan pemerintahan daerah dalam melaksanakan tugas, wewenang, kewajiban dan tanggung jawabnya serta atas kuasa peraturan perundang-undangan yang lebih tinggi dapat membuat peraturan perundang-undangan tingkat daerah atau menetapkan kebijakan daerah yang dirumuskan dalam peraturan daerah, peraturan kepala daerah dan ketentuan daerah lainnya. Beberapa bidang yang menjadi urusan pemerintah pusat meliputi: politik luar negeri; pertahanan; keamanan; yustisi; moneter dan fiskal nasional; dan agama (Pasal 10 ayat (3) UU No. 32 Tahun 2004), sedangkan urusan wajib

Ridwan Khairandy, "Iklim Investasi dan J aminan Kepastian Hukum dalam Era Otonomi Daerah", J urnal Hukum Respublica, Vol. 5, No. 2 Tahun 2006, hlm. 160 yang menjadi kewenangan pemerintahan daerah untuk kabupaten/kota merupakan urusan yang berskala kabupaten/ kota meliputi: perencanaan dan pengendalian pembangunan; perencanaan, pemanfaatan, dan pengawasan tata ruang; penyelenggaraan ketertiban umum dan ketentraman masyarakat; penyediaan sarana dan prasarana umum; penanganan bidang kesehatan; penyelenggaraan pendidikan; penanggulangan masalah sosial; pelayanan bidang ketenagakerjaan; fasilitasi pengembangan koperasi, usaha kecil dan menengah; pengendalian lingkungan hidup; pelayanan pertanahan; pelayanan kependudukan, dan catatan sipil; pelayanan administrasi umum pemerintahan; pelayanan administrasi penanaman modal; penyelenggaraan pelayanan dasar lainnya; dan urusan wajib lainnya yang diamanatkan oleh peraturan perundang-undangan (Pasal 14 ayat (1) UU No. 32 Tahun 2004).

Peraturan perundang-undangan tingkat daerah diartikan sebagai peraturan perundangundangan yang dibentuk oleh pemerintah daerah atau salah satu unsur pemerintah daerah yang berwenang membuat peraturan perundangan daerah. Materi muatan perda adalah seluruh materi muatan dalam rangka penyelenggaraan otonomi daerah dan tugas pembantuan, menampung dan mempertimbangkan ciri khas atau kondisi khusus daerah serta merupakan penjabaran lebih lanjut dari peraturan perundangan yang lebih tinggi. Materi muatan dalam perda dilarang bertentangan dengan kepentingan umum dan atau peraturan perundangan yang lebih tinggi. Berdasarkan penjelasan tersebut, berkaitan dengan kepariwisataan, pada dasarnya daerah diberikan kewenangan untuk mengurusnya sendiri.

Kabupaten Purbalingga sendiri, merupakan kabupaten yang sedang giat-giatnya membangun melalui konsep investasi. Selain investasi di bidang industri, Kabupaten Purbalingga juga sedang menata pembangunan obyek wisatanya. Julukan magnet wisata Jawa Tengah memang pantas di sandang Kabupaten Purbalingga.

Beberapa Peraturan Perundangan berkaitan dengan obyek wisata di Kabupaten Pur- 
balingga yaitu: pertama, Peraturan Daerah Kabupaten daerah Tingkat II Purbalingga Nomor 19 Tahun 1998 tentang Retribusi Tempat Rekreasi dan Olah Raga; kedua, Perda Kabupaten Purba-lingga No. 38 tahun 2005 tentang Perusahaan Daerah Obyek Wisata Air Bojongsari; dan ketiga, Perda Kabupaten Purbalingga No. 10 Tahun 2007 tentang Perubahan Atas Peraturan Daerah Kabupaten Purbalingga No. 38 tahun 2005 tentang Perusahaan Daerah Obyek Wisata Air Bojongsari Berdasarkan data tersebut tampak bahwa dari sekian banyak obyek wisata yang ditawarkan, baru satu obyek wisata yang sudah ada peraturan daerah, yaitu obyek wisata air Bojongsari (Owabong), yang telah diatur dengan Perda Kabupaten Purbalingga Nomor 38 Tahun 2005 tentang Perusahaan Daerah Obyek Wisata Air Bojongsari.

Wisatawan menurut ketentuan Pasal 1 ayat (2) UU No. 10 Tahun 2009 adalah orang yang melakukan wisata, sedangkan Pengusaha Pariwisata adalah orang atau sekelompok orang yang melakukan kegiatan usaha pariwisata ( $\mathrm{Pa}$ sal 1 ayat (8) UU No. 10 Tahun 2009, Apabila melihat rumusan tersebut, istilah wisatawan dapat dianalogikan dengan konsumen, yaitu setiap orang pemakai barang dan/atau jasa yang tersedia dalam masyarakat, baik bagi kepentingan diri sendiri, keluarga, orang lain, mau pun makhluk hidup lain dan tidak untuk diperdagangkan (Pasal 1 ayat (2) UU No. 8 Tahun 1999), sedangkan penyedia jasa kepariwisataan dapat dianalogikan sebagai pelaku usahanya, yaitu setiap orang perseorangan atau badan usaha, baik yang berbentuk badan hukum mau pun bukan badan hukum yang didirikan dan berkedudukan atau melakukan kegiatan dalam wilayah hukum negara Republik Indonesia, baik sendiri maupun bersama-sama melalui perjanjian menyelenggarakan kegiatan usaha dalam berbagai bidang ekonomi (Pasal 1 ayat (3) UU No. 8 Tahun 1999). Pelaku usaha dapat berupa perusahaan, korporasi, BUMN, koperasi, importer, pedagang maupun distributor.

Peraturan daerah yang ada di Kabupaten Purbalingga, apabila dihubungkan dengan penjelasan tersebut di atas, maka dapat diinterpretasikan bahwa Pemerintah Daerah Kabupa- ten Purbalingga belum menempatkan konsumen, dalam hal ini wisatawan, sebagai sasaran utama dalam usaha menggali pendapatan asli daerah. Pemerintah Daerah Kabupaten Purbalingga masih bersifat pragmatis dalam usaha menggali pendapatan asli daerah, terutama dalam bidang kepariwisataan, yaitu dengan berusaha mendapatkan keuntungan sebesarnya melalui pembentukan perusahaan daerah maupun dengan penarikan retribusi.

Perlindungan konsumen seharusnya menjadi perhatian lebih mengingat investasi, khususnya dalam bidang kepariwisataan, telah menjadi bagian pembangunan ekonomi. Perlindungan konsumen sendiri dapat dilakukan dengan: pertama, menciptakan sistem perlindungan konsumen yang mengandung unsur keterbukaan akses dan informasi serta menjamin kepastian hukum; kedua, melindungi kepentingan konsumen pada khususnya dan pelaku usaha pada umumnya; ketiga, meningkatkan kualitas barang dan pelayanan jasa; keempat, memberikan perlindungan kepada konsumen dari praktik usaha yang menipu dan menyesatkan; dan kelima, memadukan penyelenggaraan, pengembangan dan pengaturan perlindungan konsumen dengan bidang lainnya; ${ }^{7}$

Konsumen, apabila dihubungkan dengan kekuatan pasar, pada dasarnya mempunyai kekuatan di pasar. Permintaan konsumen menentukan sukses tidaknya sebuah produk atau jasa. Bahkan di negara maju, salah satu tantangan terbesar perusahaan adalah menciptakan kredibilitas konsumen. Beberapa langkah yang dilakukan antara lain meliputi: keterlibatan masyarakat, iklan-iklan penjualan yang baik, dan keakraban dalam hubungan antar manusia dan kesopansantunan dalam semua urusan, bahkan pelaku usaha menyediakan ganti rugi dan pendidikan bagi konsumen. ${ }^{8}$ Berkaitan hak

\footnotetext{
Maslihati Nur Hidayati. "Analisis tentang Alternatif Penyelesaian Sengketa Perlindungan Konsumen: Studi tentang Efektivitas Badan Penyelesaian Sengketa Perlindungan Konsumen". Lex J urnalica Vol. 5 No. 3, Agustus 2008. Hal. 170

8 Sri Sumiyati dan Rini Fatmasari. "Peranan yayasan Lembaga Konsumen Dalam Memberikan Perlindungan Konsumen". Jurnal Pena Wiyata. Jurdik dan Hum. No. 9 tahun V, September 2006, hal. 78
} 
dan kewajiban pelaku usaha dan konsumen dapat dijelaskan sebagai berikut:

Pelaku usaha mempunyai hak untuk: pertama, menerima pembayaran sesuai dengan kesepakatan mengenai kondisi dan nilai tukar barang dan/atau jasa yang diperdagangkan; kedua, mendapat perlindungan hukum dari tindakan konsumen yang beritikad tidak baik; ketiga, melakukan pembelaan diri sepatutnya dalam rangka penyelesaian sengketa dengan konsumen; dan keempat, rehabilitasi nama baik apabila terbukti secara hukum bahwa kerugian konsumen tidak diakibatkan oleh barang dan/ atau jasa yang diperdangangkan. Hak-hak pelaku usaha selain diatur dalam UU Nomor 8 Tahun 1999 juga diatur dalam undang-undang lainnya seperti Undang-undang Perbankkan, Undangundang Larangan Praktek Monopoli dan Persaingan Usaha Tidak Sehat, Undang-undang Pangan.

Kewajiban pelaku usaha antara lain: pertama, beritikad baik dalam melakukan kegiatan usaha; kedua, memberi informasi yang benar, jelas dan jujur mengenai kondisi dan jaminan barang dan/atau jasa, serta memberi penjelasan penggunaan, perbaikan dan pemeliharaan barang dan/atau jasa; ketiga, memperlakukan atau melayani konsumen secara benar dan jujur, serta tidak diskriminatif; keempat, menjamin mutu barang dan/atau jasa yang diproduksi dan/ atau diperdagangkan berdasarkan ketentuan standar mutu barang dan/atau jasa yang berlaku; kelima, memberi kesempatan kepada konsumen untuk menguji dan/atau mencoba barang dan/atau jasa serta memberi jaminan dan/ atau garansi atas barang yang dibuat dan/ atau diperdagangkan; dan keenam, memberi kompensasi, ganti rugi dan/atau penggantian apabila barang dan/atau jasa yang diterima atau dimanfaatkan konsumen tidak sesuai dengan perjanjian.

Hak-hak konsumen diatur di dalam Pasal 4 Undang-Undang No. 8 Tahun 1999, yang menentukan bahwa :

Hak konsumen, adalah :

a. hak atas kenyamanan, keamanan, dan keselamatan dalam mengkonsumsi barang dan/ atau jasa; b. hak untuk memilih dan mendapatkan barang dan/atau jasa sesuai dengan nilai tukar dan kondisi serta jaminan yang dijanjikan;

c. hak atas informasi yang benar, jelas, dan jujur mengenai kondisi dan jaminan barang dan/ atau jasa;

d. hak untuk didengar pendapat dan keluhannya atas barang dan/atau jasa yang digunakan;

e. hak untuk mendapatkan advokasi, perlindungan, dan upaya penyelesaian sengketa perlindungan konsumen secara patut;

f. hak untuk mendapat pembinaan dan pendidikan konsumen;

g. hak untuk diperlakukan atau dilayani secara benar dan jujur serta tidak diskrimanatif.

h. Hak untuk mendapatkan kompensasi, ganti rugi dan/atau penggantian, apabila barang dan/atau jasa yang diterima tidak sesuai dengan perjanjian atau tidak sebagaiman mestinya;

i. Hak-hak yang diatur dalam ketentuan peraturan perundang-undangan lainnya.

Pada dasarnya hak-hak konsumen tersebut di atas, dapat disimpulkan menjadi 3 (tiga) hak yang menjadi prinsip dasar. Pertama, hak atas perlindungan dari kerugian, baik kerugian personal maupun kerugian harta kekayaan; kedua, hak untuk memperoleh barang atau jasa dengan harga yang wajar; dan ketiga, hak untuk memperoleh penyelesaian terhadap permasalahan yang dihadapi.

Kewajiban konsumen diatur dalam Pasal 5 Undang-Undang No. 8 Tahun 1999 yang menentukan hal-hal sebagai berikut

Kewajiban konsumen, adalah :

a. membaca atau mengikuti petunjuk informasi dan prosedur pemakaian atau pemanfaatan barang dan/atau jasa demi keamanan dan keselamatan;

b. beriktikad baik dalam melakukan transaksi pembelian baran dan/ atau jasa;

c. membayar sesuai dengan nilai tukar yang disepakati;

d. mengikuti upaya penyelesaian hukum sengketa perlindungan konsumen secara patut." 
Kewajiban konsumen untuk membaca atau mengikuti petunjuk informasi dan prosedur pemakaian atau pemanfaatan barang dan/atau jasa ditujukan demi keamanan dan keselamatan konsumen sendiri. Ketentuan Pasal 4 UU No. 8 Tahun 1999, yang mengatur bahwa konsumen berhak atas kenyamanan, keamanan, dan keselamatan dalam mengonsumsi barang dan/atau jasa, apabila dihubungkan dengan Pasal 26 huruf d UU No. 10 Tahun 2009, yang mengatur bahwa setiap pengusaha pariwisata berkewajiban memberikan kenyamanan, keramahan, perlindungan keamanan, dan keselamatan wisatawan, maka dapat diinterpretasikan bahwa perlindungan keamanan, baik fisik, jiwa mau pun barang bawaan menjadi tanggung jawab pengu-saha pariwisata.

Berkaitan dengan hak konsumen untuk mendapatkan ganti rugi, berdasarkan informasi yang diperoleh di Kantor J asa Raharja Kabu-paten Purbalingga, bahwa antara Jasa Raharja dengan Perusahaan Daerah Owabong telah melaksanakan suatu Memorandum of Understanding (MoU) tentang penentuan ganti kerugian. Dalam hal ini penulis tidak dapat menggali lebih dalam mengenai MoU tersebut, karena pihak yang berkepentingan berpandangan bahwa MoU tersebut hanya diperuntukkan bagi para pihak, sehingga pihak lain tidak perlu mengetahui MoU tersebut. Terlepas dari tidak diperolehnya MoU tersebut, pada dasarnya telah terdapat itikad baik dari pelaku usaha, dalam hal ini Perusahaan Daerah Owabong, untuk memberikan ganti rugi. Namun demikian, ganti kerugian yang diberikan oleh jasa Raharja hanya terbatas pada kecelakaan fisik saja sebagai akibat kunjungan wisatawan ke obyek wisata, sedangkan kerugian yang disebabkan selain kecelakaan fisik tersebut tidak diatur lebih lanjut, seperti kecopetan maupun kehilangan barang bawaan. Hal terakhir ini menitikberatkan pada aspek keamanan yang harus diberikan di obyek wisata.

Sumber pendapatan asli daerah (PAD) merupakan sumber keuangan daerah yang digali dari dalam wilayah daerah yang bersangkutan yang dapat berupa hasil pajak daerah, hasil retribusi daerah, hasil pengelolaan kekayaan dae- rah. Berlakunya undang-undang otonomi daerah mengakibatkan pemerintah daerah dituntut untuk menggali sumber pendapatan asli daerah, karena tidak mungkin terus menggantungkan bantuan dari pusat saja untuk membiayai pembangunan. ${ }^{9}$ Pada era otonomi daerah pemerintah daerah memiliki otonomi penuh yang di jamin oleh konstitusi negara untuk mengatur dan mengurus urusan rumah tangganya sendiri. Pada sistem ini dikenal adanya urusan pemerintah yang tetap menjadi wewenang penuh pemerintah pusat yang meliputi urusan keimigrasian, moneter, pertahanan, keamanan, peradilan dan sebagian pendidikan masih di tangan pemerintah pusat, meskipun pelaksanaannya oleh pemerintah daerah.

Merujuk pada semangat otonomi daerah yang digariskan UU No. 32 Tahun 2004 tentang Pemerintahan daerah, pada dasarnya dalam usaha memberikan perlindungan hukum bagi wisatawan, pemerintah daerah dapat membentuk suatu regulasi berupa Peraturan Daerah yang secara umum mengatur mengenai perlindungan konsumen, khususnya wisatawan. Peraturan daerah ini dapat dibentuk, sepanjang tidak bertentangan dengan asas peraturan perundangangan, meliputi: Peraturan perundangan tidak berlaku surut (non retroaktif); Peraturan perundang-undangan yang dibuat oleh penguasa yang lebih tinggi, mempunyai kedudukan yang lebih tinggi pula; Peraturan perundangan yang bersifat khusus menyampingkan peraturan perundang-undangan yang bersifat umum (lex specialis derogat lex generalis); Peraturan perundang-undangan yang berlaku belakangan membatalkan peraturan perundang-undangan yang berlaku terdahulu (lex posteriori derogate lex periori); Peraturan perundang-undangan tidak dapat diganggu gugat; dan Peraturan perundang-undangan sebagai sarana untuk semaksimal mungkin dapat mencapai kesejahteraan spiritual dan materil bagi masyarakat maupun individu, melalui pembaharuan atau pelestarian (asas welvaarstaat).

Hadion Wijoyo, "Problematika Hukum di Bidang Investasi dalam Era Otonomi Daerah", J urnal Hukum Respublica, Vol. 5 No. 2, Tahun 2006, hlm. 162 


\section{Upaya Hukum Bagi Wisatawan yang Menderita Kerugian di Obyek Wisata}

Hubungan hukum adalah hubungan yang diatur oleh hukum dan menjadi obyek hukum. Dalam hukum perdata diatur tentang hak dan kewajiban orang-orang yang mengadakan hubungan hukum meliputi peraturan yang bersifat tertulis dan yang bersifat tidak tertulis berupa peraturan hukum adat dan kebiasaan yang hidup di dalam masyarakat.

Pelaksanaan hukum materiil perdata, dapat berlangsung secara diam-diam di antara para pihak yang bersangkutan tanpa melalui pejabat atau instansi resmi. Namun demikian dapat terjadi kemungkinan, bahwa hukum materiil perdata itu dilanggar, sehingga ada pihak yang dirugikan dan terjadilah gangguan keseimbangan kepen-tingan di dalam masyarakat. Hukum materiil perdata yang telah dilanggar itu harus dipertahankan atau ditegakkan, karena setiap warga negara memiliki hak yang sama dihadapan hukum dan ia pun berhak untuk membela haknya apabila ia merasa dirugikan oleh pihak lain. Pada hubungan hukum yang bersifat obligatur, apabila salah satu pihaknya tidak melaksanakan kewajiban, maka pada pihak lain terdapat pelanggaran hak, sehingga timbul suatu sengketa.

Penyelesaian sengketa dapat dibedakan antara penyelesaian sengketa secara damai dan penyelesaian sengketa secara adversarial. Penyelesaian sengketa secara damai lebih dikenal dengan penyelesaian secara musyawarah mufakat. Sementara penyelesaian sengketa secara adversial lebih dikenal dengan penyelesaian sengketa oleh pihak ketiga yang tidak terlibat dalam sengketa.

Pada penyelesaian sengketa secara damai tidak ada pihak yang mengambil keputusan bagi penyelesaian sengketa. Keterlibatan pihak ketiga dalam penyelesaian sengketa secara damai adalah dalam rangka mengusahakan agar para pihak yang bersengketa dapat sepakat untuk menyelesaian sengketa mereka. Bentuk penyelesaian sengketa secara damai adalah negosiasi, mediasi dan konsiliasi. Negosiasi merupakan penyelesaian sengketa secara damai di mana para pihak berhadapan langsung tanpa ada keikutsertaan dari pihak ketiga. Mediasi dan konsiliasi adalah penyelesaian sengketa secara damai dimana ada turut campur pihak ketiga. Perbedaan antara konsiliasi dan mediasi terletak pada aktif tidaknya pihak ketiga dalam mengusahakan para pihak untuk menyelesaikan sengketa. Penyelesaian ini merupakan hal yang ideal mengingat keadilan muncul dari para pihak. Penyelesaian sengketa secara damai menyaratkan ada-nya kesukarelaan dari pihak-pihak yang bersengketa. Tanpa adanya kesukarelaan di antara para pihak, tidak mungkin penyelesaian seng-keta secara damai berjalan.

Penyelesaian sengketa secara adversial melalui lembaga arbitrase, keadilan untuk para pihak yang bersengketa berasal dari arbiter. Penyelesaian melalui arbitrase menghasilkan putusan. Hukum di Indonesia yang mengatur tentang arbitrase adalah UU No. 30 Tahun 1999 tentang Arbitrase dan Alternatif Penyelesaian Sengketa. Arbitrase diartikan sebagai lembaga penyelesaian sengketa atau beda pendapat melalui prosedur yang disepakati para pihak, yakni penyelesaian di luar pengadilan dengan cara konsultasi, negosiasi, mediasi, konsiliasi, atau penilaian ahli. Penyelesaian sengketa melalui arbitrase, keadilan untuk para pihak yang bersengketa berasal dari arbiter.

Keuntungan penyelesaian sengketa melalui larbitrase adalah banyak hal yang bersifat fleksibel dan konsensual. Penyelesaian sengketa melalui arbitrase tidak formal dan kaku. Proses penyelesaian sengketa pun dapat dirahasiakan, di mana selain para pihak yang bersengketa dan para arbiter tidak boleh diikuti oleh pihak ketiga. Penyelesaian sengketa melalui arbitrase merupakan penyelesaian yang jauh dari inter-vensi pemerintah dan menghasilkan putusan akhir yang tidak dapat dibanding. Penyelesaian sengketa melalui arbitrase dianggap lebih cepat dibandingkan dengan penyelesaian sengketa melalui pengadilan yang berjenjang. Keuntungan lain adalah putusan yang dibuat bersifat netral dan dilakukan oleh orang-orang yang tahu permasalahan. Para arbiter tidak harus mereka yang menyandang gelar sarjana hukum. Para arbiter dapat berasal dari mereka yang ahli di suatu bidang tertentu, seperti 
konstruksi, perasuransian, perbankan, pasar modal maupun lingkungan hidup.

Sementara kekurangan dari digunakannya penyelesaian sengketa melalui arbitrase diantaranya adalah mahal. Hal ini disebabkan, para pihak yang bersengketa harus membiayai berbagai keperluan, mulai dari honor arbiter yang menyelesaikan sengketa hingga biaya sewa ruangan, biaya kesekretariatan maupun biaya telepon. Selain itu, lembaga arbitrase yang bersifat permanen tidak dapat ditemukan secara mudah. Lembaga arbitrase yang bersifat permanen hanya ada dikota-kota besar. Ini berbeda dengan pengadilan dimana di setiap kabupaten dan kota terdapat pengadilan yang berwenang untuk menyelesaikan sengketa.

Proses dan prosedur arbitrase tidaklah mudah, sehingga hanya masyarakat pada stratifikasi sosial tertentu yang dapat memanfaatkan. Arbitrase tidak umum dimanfaatkan oleh pelaku usaha yang kurang terdidik ataupun kelas bawah. Di Indonesia penyelesaian melalui arbi-trase hanya bisa dilakukan pada sengketa yang bersifat dagang (commercial dispute). Hal ini ditegaskan dalam Pasal 5 ayat 1 Undangundang Arbitrase yang menyebutkan, "Sengketa yang dapat diselesaikan melelui arbitrase hanya sengketa dibidang perdangan."

Sebelum dibahas tentang klausul arbitrase, maka ada baiknya diperhatikan ketentuan Undang-undang Arbitrase yang relevan untuk di jadikan rujukan, yaitu Pasal 1 ayat (3) Undangundang Arbitrase, yang mengatur bahwa:

Perjanjian arbitrase adalah suatu kesepakatan berupa klausul abitrase yang tercantum dalam perjanjian tertulis yang di buat para pihak sebelum timbul sengketa, atau suatu perjanjian arbitrase tersendiri yang dibuat para pihak setelah timbul sengketa.

Selanjutnya Pasal 9 ayat (1) Undang-undang Arbitrase mengatur bahwa dalam hal para pihak memilih penyelesaian sengketa melelui arbitrase setelah sengketa terjadi, persetujuan mengenai hal tersebut harus dibuat dalam suatu perjanjian tertulis yang ditandatangani oleh para pihak. Berdasarkan kedua pasal tersebut di atas, maka ada dua jenis perjanjian abitrase.
Pertama adalah perjanjian arbitrase berupa klausul arbitrase dalam suatu perjanjian. Kedua adalah perjanjian arbitrase yang dibuat secara tersendiri dan terpisah dari perjanjian yang dibuat oleh para pihak sebelum terjadinya sengketa. Kedua jenis perjanjian arbitrase tersebut menggariskan bahwa untuk sahnya suatu perjanjian arbitrase harus dipenuhi syarat, yaitu telah disepakati oleh para pihak yang membuat perjanjian atau para pihak yang terlibat dalam sengketa dan kesepakatan harus dilakukan secara tertulis oleh para pihak yang bersengketa.

Arbitrase tidak dapat memeriksa dan memutuskan sengketa tanpa didasari adanya perjanjian arbitrase yang dibuat secara tertulis. $\mathrm{Hal}$ ini mengingat elemen penting yang diatur dalam Undang-undang Arbitase adalah perjanjian arbitrase, baik sebelum maupun setelah terjadinya sengketa, harus dibuat dalam bentuk tertulis.

Klausul arbitrase yang baik harus memenuhi paling tidak enam unsur. Keenam unsur tersebut adalah tempat dilaksakannya arbitrase, hukum acara untuk pelaksanaan arbitrase, tata cara penunjukan arbiter dan pihak yang berwenang untuk menunjuk arbitrase (apabila perlu), jumlah dari arbiter, hukum yang berlaku dan bahasa yang digunakan dalam proses arbitrase.

Penyelesaian sengketa melelui arbitrase dapat dilakukan secara ad hoc dan secara institusional/permanen. Lembaga arbitrase ad hoc merupakan arbitrase dibentuk untuk menyelesaikan sengketa dan ketika proses telah selesai, maka arbitrase tersebut langsung dibubarkan. Sementara penyelesaian melalui arbitrase yang dilakukan secara institusional, penyelesaian dilakukan oleh suatu badan atau lembaga arbitrase. Badan atau lembaga arbitrase ini didirikan oleh pihak-pihak tertentu. Pada arbitrase semacam ini, hukum acara, daftar arbiter dan nama, serta kredibilitas untuk menyelesaikan sengketa telah dimiliki.

Penyelesaian sengketa dengan menggunakan jasa pihak ketiga harus memperhatikan beberapa prinsip. Pertama, para pihak secara suka rela bersedia dan berkeinginan menyelesaikan sengketa secara bermusyawarah; kedua, 
pihak ketiga yang bertindak sebagai fasilitator/ mediator/arbiter di setuj ui oleh para pihak dan harus netral; ketiga, masing-masing pihak tidak bertahan pada posisinya; keempat, para pihak tidak mempunyai kecurigaan yang berlebihan; dan kelima, persyaratan atau bentuk tuntutan harus rasional.

Pelaksanaan putusan arbitrase merupakan suatu keadaan dimana putusan telah dibuat oleh arbiter namun tidak dijalankan secara sukarela oleh pihak yang dikalahkan dan dalam hal ini pihak yang dimenangkan memiliki upaya hukum berupa pelaksanaan putusan arbitrase atau yang lebih dikenal dengan istilah eksekusi putusan arbitrase. Pelaksanaan putusan arbitrase merupakan upaya paksa yang dimohonkan oleh pihak yang dimenangkan dalam suatu arbitrase. Pihak yang dimenangkan ini memohon ke pengadilan untuk melakukan upaya paksa.

Pelaksanaan putusan arbitrase dapat di lakukan atas putusan arbitrase yang dibuat di dalam negeri (putusan arbitrase nasional/domestik) dan putusan arbitrase yang dibuat di luar negeri (putusan arbitrase internasional/asing). Putusan arbitrase domestik berlaku ketentuan Pasal 59 s. d. Pasal 64 UU Arbitrase. Sementara untuk putusan arbitrase internasional berlaku ketentuan Pasal 65 sampai Pasal 69 UU Arbitrase.

Diakuinya putusan arbitrase internasional di Indonesia didasarkan pada keikutsertaan Indonesia dalam sebuah perjanjian internasional yang disebut sebagai Convention on the Recog-nition and Enforcement of Foreign Arbitral Awards (konvensi tentang Pengakuan dan Pelaksanaan Putusan Arbitrase Asing) atau yang lebih dikenal dengan Konvensi New York 1958. Inti dari Konvensi ini adalah negara yang menjadi peserta harus mengakui dan melaksanakan putusan arbitrase yang dibuat di luar negeri sepanjang negara dimana arbitrase dilangsungkan telah juga menjadi peserta dari Konvensi. Suatu putusan arbitrase asing dapat diakui dan dilaksanakan di Indonesia, apabila putusan tersebut terlebih dahulu diserahkan dan didaftarkan oleh arbiter atau kuasanya di Pengadilan
Negeri J akarta Pusat dengan menyampaikan putusan asli atau salinan sahnya. ${ }^{10}$

Setelah putusan dibuat dan diucapkan pihak yang dikalahkan dapat melakukan dua alternatif upaya hukum. Pertama yaitu upaya hukum berupa penolakan pelaksanaan atau eksekusi (enforcement) atas Putusan Arbitrase Internasional kepada pengadilan dimana aset atau barang berbeda. Hal ini terjadi mengingat putusan arbitrase dibuat di suatu negara tetapi pelak-sanaannya dilakukan di negara lain. Putusan Arbitrase Internasional pada umumnya memiliki karakter demikian; pelaksanaan putusan akan sangat bergantung pada dimana aset atau barang yang hendak dieksekusi berada. Pelibatan pengadilan tidak dapat dihindari mengingat pemaksaan atas putusan hanya bisa dilakukan oleh pengadilan dalam bentuk penetapan eksekusi.

Upaya hukum kedua adalah pihak yang dikalahkan dapat "memasalahkan" Putusan Arbitrase Internasional yang telah dibuat. Upaya hukum ini pada dasarnya adalah upaya hukum untuk membatalkan putusan arbitrase. Dalam upaya hukum ini, sama seperti upaya hukum pertama, memerlukan keterlibatan pengadilan. Pengadilan dianggap sebagai otoritas yang berwenang untuk membatalkan putusan arbitrase.

Pengadilan tidak berwenang untuk memeriksa pokok perkara yang dipersengketakan oleh para pihak dalam proses pembatalan. Kewenangan pengadilan hanya terbatas pada kewenangan untuk memeriksa keabsahan dari segi prosedur pengambilan putusan arbitrase, antara lain proses pemilihan para arbiter hingga pemberlakuan hukum yang dipilih oleh para pihak dalam penyelesaian sengketa. Alasan ini dan alasan lainnya sebagai dasar pembatalan putusan arbitrase lazimnya diatur dalam hukum arbitrase dari suatu negara. Penolakan putusan arbitrase oleh pengadilan tidak berarti tidak mengakui putusan tersebut. Penolakan mempunyai konsekuensi tidak dapatnya putusan arbitrase dilaksanakan di yurisdiksi pengadilan

10 Iriansyah, "Pelaksanaan Putusan Arbitrase Asing dalam Penyelesian Sengketa Investasi di Indonesia", Jurnal Hu-kum Respublica, Vol. 6, No. 2, Tahun 2007, hlm. 190 
yang telah menolaknya apabila ternyata di negara lain terdapat aset dari pihak yang dikalahkan, pihak yang dimenangkan masih dapat meminta eksekusi di pengadilan negara tersebut.

Penyelesaian sengketa di luar pengadilan merupakan pilihan para pihak dan bersifat sukarela. Para pihak juga bebas untuk menentukan lembaga penyedia jasa yang membantu penyelesaian sengketa. Lembaga penyedia jasa menyediakan pelayanan penyelesaian sengketa dengan menggunakan bantuan arbiter atau mediator atau pihak ketiga lainnya. Apabila para pihak telah memilih upaya penyelesaian sengketa di luar pengadilan, gugatan melalui pengadilan hanya dapat di tempuh apabila upaya tersebut dinyatakan tidak berhasil secara tertulis oleh salah satu atau para pihak yang bersengketa atau salah satu atau para pihak yang bersengketa menarik diri dari perundingan.

Berkaitan dengan sengketa konsumen, penyelesaian sengketa selain melalui arbitrase, juga dapat dilakukan melalui Badan Penyelesaian Sengketa Perlindungan Konsumen sebagaimana diatur dalam UU No. 8 Tahun 1999 (selanjutnya disebut UUPK). BPSK sebagaimana dimaksud dalam UUPK, yang dibentuk oleh pemerintah, adalah badan yang bertugas menangani dan menyelesaikan sengketa antara pelaku usaha dan konsumen, tetapi bukanlah merupakan bagian dan institusi kekuasaan kehakiman. Pemerintah membentuk BPSK Tingkat II untuk menyelesaikan sengketa konsumen di luar pengadilan, akan tetapi BPSK bukanlah lembaga pengadilan.

BPSK mempunyai anggota-anggota dari unsur pemerintah, konsumen dan pelaku usaha. Setiap unsur tersebut berjumlah 3 (tiga) orang atau sebanyak-banyaknya 5 (lima) orang yang kesemuanya diangkat dan diberhentikan oleh Menteri Perindustrian dan Perdagangan. Keanggotaan Badan terdiri dari ketua merangkap anggota, wakil ketua merangkap anggota dan anggota dngan dibantu oleh sekretaris. Tugas dan wewenang BPSK meliputi: pertama, penyelesaian sengketa konsumen melalui mediasi, arbitrase atau konsiliasi; kedua, konsultasi perlindungan konsumen; ketiga, pengawasan klau-sul baku; keempat, pelaporan kepada penyidik umum, apabila terjadi pelanggaran undang-undang ini; kelima, penerimaan pengaduan dari konsumen baik secara lisan maupun tertulis; keenam; penelitian dan pemeriksaan tentang sengketa konsumen; ketujuh, pemanggilan terhadap pelaku usaha yang melanggar; kedelapan, menghadirkan saksi, saksi ahli dan/atau setiap orang yang dianggap mengetahui pelanggaran itu; kesembilan, meminta bantuan penyidik untuk menghadirkan mereka tersebut di atas apabila tidak mau memenuhi panggilan; kesepuluh, mendapatkan, meneliti dan/atau menilai surat, dokumen atau alat-alat bukti lain guna penyelidikan dan/atau pemeriksaan; kesebelas, memutuskan dan menetapkan ada tidaknya kerugian konsumen; keduabelas, pemberitahuan keputusan kepada pelaku usaha pelanggaran undang-undang; dan ketigabelas, penjatuhan sanksi administratif kepada pelaku usaha pe-langgar undang-undang.

BPSK dalam menyelesaikan sengketa konsumen, membentuk majelis yang terdiri dari setidaknya 3 (tiga) anggota dibantu oleh seorang panitera. Putusan BPSK bersifat final dan mengikat. BPSK wajib menjatuhkan putusan selama-lamanya 21 (duapuluh satu) hari sejak gugatan diterima dan keputusan BPSK wajib dilaksanakan pelaku usaha dalam jangka waktu 7 (tujuh) hari setelah putusan diterimanya, atau apabila ia keberatan dapat mengajukannya kepada Pengadilan Negeri dalam jangka waktu 14 (empat belas hari), pengadilan negeri yang menerima keberatan pelaku usaha memutus perkara tersebut dalam jangka waktu 21 hari sejak diterimanya keberatan tersebut. Selanjutnya kasasi pada putusan pengadilan negeri ini diberi jangka waktu 14 hari untuk mengajukan kasasi kepada Mahkamah Agung. Keputusan Mahkamah Agung wajib dikeluarkan dalam jangka waktu 30 (tiga puluh) hari sejak permohonan kasasi

Lembaga penyelesaian di luar pengadilan yang dilaksanakan oleh BPSK ini memang dikhususkan bagi konsumen dan pelaku usaha yang pada umumnya meliputi jumlah nilai yang kecil, tetapi dalam pelaksanaannya tidak ada batasan nilai pengajuan gugatan, sehingga dimungkinkan gugatan konsumen meliputi jum- 
lah nilai yang kecil sampai nilai yang besar. Meskipun BPSK bukan pengadilan dan lebih tepat disebut dengan peradilan semu tetapi keberadaannya bukanlah sekedar tampil sebagai pengakuan hak konsumen untuk mendapatkan perlindungan dalam upaya penyelesaian sengketa konsumen secara patut, tetapi keberadaannya yang lebih penting adalah melakukan pengawasan terhadap pencantuman klausul baku (one-sided standard form contract) oleh pelaku usaha dan untuk mendorong kepatuhan pelaku usaha pada UUPK.

Putusan BPSK sebagai hasil dari penyelesaian sengketa konsumen secara konsiliasi, mdiasi atau arbitrase, bersifat final dan mengikat. Pengertian final berarti bahwa penyelesaian sengketa telah selesai dan berakhir, sedangkan kata mengikat mengandung arti memaksa dan sebagai sesuatu yang harus dijalankan oleh pihak yang diwajibkan untuk itu. Prinsip res judicata pro veritate habetur, menyatakan bahwa suatu putusan yang tidak mungkin lagi untuk ditakukan upaya hukum, dinyatakan sebagai putusan yang mempunyai kekuatan hukum yang pasti. Berdasarkan prinsip tersebut, putusan BPSK harus dipandang sebagai putusan yang mempunyai kekuatan hukum yang pasti (in kracht van gewijsde). Ketentuan pasal tersebut apabila dihubungkan dengan Pasal 56 ayat (2) UUPK dapat diinterpretasikan bahwa para pihak dapat mengajukan keberatan kepada pengadilan negeri paling lambat 14 hari kerja setelah pemberitahuan putusan BPSK. Hal ini bertentangan dengan pengertian putusan BPSK yang bersifat final dan mengikat tersebut, sehingga dengan demikian ketentuan pasal-pasal tersebut saling kontradiktif dan menjadi tidak efisien. Menyikapi adanya permasalahan hukum hukum yang ditimbulkan oleh Undang-undang Perlindungan Konsumen, terbitlah Peraturan Mahkamah Agung (PERMA) yang bertujuan untuk menjembatani kekosongan prosedural sangatlah dibutuhkan, yaitu PERMA No. I Tahun 2006 mengenai Tata Cara Pengajuan Upaya Hukum Keberatan Terhadap Putusan BPSK. PERMA ini mengatur bahwa keberatan merupakan upaya hukum yang hanya dapat diajukan terhadap putusan arbitrase yang dikeluarkan oleh BPSK, tidak meliputi putusan BPSK yang timbul dari mediasi dan konsiliasi. Putusan mediasi dan konsiliasi dapat disepadankan dengan adanya suatu perdamaian (dading) di luar atau di dalam pengadilan, sehingga putusannya bersifat final dan mengikat.

Putusan arbitrase BPSK, meskipun digunakan terminologi arbitrase, tetapi UUPK sama se-kali tidak mengatur mekanisme arbitrase seperti yang ditentukan dalam UU No. 30 Tahun 1999 tentang Arbitrase dan Alternatif Penyelesaian Sengketa, melainkan membuat suatu aturan ter-sendiri yang relatif berbeda dengan apa yang telah ditentukan dalam UU No. 30 tahun 1999 tersebut, sehingga timbul pertentangan antara arbitrase dalam putusan BPSK, dengan putusan arbitrase dalam UU No. 30 tahun 1999, yang memerlukan penafsiran lebih lanjut. Ketidak jelasan peraturan dalam UUPK ini menimbulkan kebingungan dalam pengimplementasiannya.

Putusan BPSK, agar mempunyai kekuatan eksekusi, putusan tersebut harus dimintakan penetapan fiat eksekusi pada pengadilan negeri di tempat tinggal konsumen yang dirugikan. Dalam praktek timbul kesulitan untuk meminta fiat eksekusi melalui pengadilan negeri, karena berbagai alasan yang dikemukakan oleh pengadilan negeri antara lain: pertama, putusan BPSK tidak memuat irah-irah "Demi Keadilan Berda-sarkan Ketuhanan Yang Maha Esa", sehingga tidak mungkin dapat dieksekusi; dan kedua, belum terdapat peraturan/petunjuk tentang tata cara mengajukan pcrmohonan eksekusi terhadap putusan BPSK.

Masalah lain sehubungan dengan fiat eksekusi adalah pengaturan oleh Pasal 42 ayat (2) Keputusan Menperindag No. 350/MPP/ Kep/t2/ 2000 yang mengatur bahwa terhadap putusan BPSK dimintakan penetapan eksekusi oleh BPSK kepada pengadilan negeri di tempat konsumen yang dirugikan. Pengaturan semacam ini dalam hukum acara perdata tidak lazim, karena permohonan eksekusi adalah demi kepentingan pihak yang dimenangkan dalam putusan. Oleh karena itu, yang seharusnya mengajukan permohonan penetapan eksekusi adalah pihak yang berkepentingan sendiri bukan lembaga BPSK. 
Pelaku usaha, apabila setelah menerima pemberitahuan atas keputusan BPSK tidak setuju atau berkeberatan terhadap putusan tersebut dan mengajukan permohonan keberatan kepada pengadilan negeri, maka timbul suatu permasalahan, dikarenakan keberatan bukanlah suatu upaya hukum yang dikenal dalam hukum acara di Indonesia, dan UUPK tidak memberikan suatu petunjuk teknis bagaimana prosedur pengajuan permohonan keberatan ini diajukan, dan bagaimana pengadilan negeri memproses permohonan keberatannya mengingat belum ada acara yang secara jelas mengatur perihal proses keberatan ini.

Sanksi administratif diatur pada Pasal 60 UUPK. Sanksi administratif ini merupakan suatu hak khusus yang diberikan oleh UUPK kepada BPSK atas tugas dan/atau kewenangan yang diberikan untuk menyelesaikan sengketa konsumen di luar pengadilan. Sanksi administratif, menurut ketentuan Pasal 60 ayat (2) jo Pasal 60 ayat (1) UUPK, yang dapat dijatuhkan oleh BPSK adalah berupa penetapan ganti rugi sampai setinggi-tingginya $\mathrm{Rp} 200,000.000,00$ (dua ratus juta rupiah) yang dijatuhkan terha-dap pelaku usaha yang melakukan pelanggaran terhadap/ dalam rangka: pertama, tidak dilaksanakannya pemberian ganti rugi oleh pelaku usaha kepada konsumen, dalam bentuk pengembalian uang atau penggantian barang dan/ atau jasa yang sejenis, maupun perawatan kesehatan atau pemberian santunan atas kerugian yang diderita oleh konsumen; kedua, terjadinya kerugian sebagai akibat kegiatan produksi iklan yang diiakukan oleh pelaku usaha periklanan; dan ketiga, pelaku usaha yang tidak dapat menyediakan fasilitas jaminan purna jual, baik dalam bentuk suku cadang maupun peme-liharaannya, serta pemberian jaminan atau garansi yang telah ditetapkan sebelumnya, baik berlaku terhadap pelaku usaha yang memperdagangkan barang dan/atau jasa. Ketentuan tersebut memperjelas, bahwa BPSK memang tidak memiiki kewenangan untuk menjatuhkan sanksi atas setiap pelanggaran yang dilakukan oleh pelaku usaha. Hal ini sejalan dengan ketentuan Pasal 47 UUPK yang mengatur bahwa penyelesaian sengketa di luar pengadilan dise- lenggarakan untuk mencapat kesepatakan mengenai tindakan tertentu untuk menjamtn tidak akan terjadi kembali atau tidak akan terulang kembali kerugian yang diderita oleh konsumen. Namun demikian, UUPK guna menegakkan kepastian hukum, sesuai proporsinya telah memberikan hak dan kewenangan kepada BPSK untuk menjatuhkan sanksi administratif bagi pelaku usaha yang tidak memberikan ganti rugi kepada konsumen atas tindakannya yang merugikan konsumen. Berjalan atau tidaknya sanksisanksi yang telah ditentukan, sangat bergantung pada siap tidaknya berbagai pihak yang terkait termasuk BPSK.

Penyelesaian sengketa secara adversial selain melalui arbitrase juga dapat dilakukan melalui litigasi (jalur pengadilan). Salah satu unsur negara hukum adalah berfungsinya kekuasaan kehakiman yang merdeka yang dilakukan oleh badan peradilan. Kekuasaan kehakiman merupakan kekuasaan negara yang merdeka untuk menyelenggarakan peradilan guna menegakkan hukum dan keadilan berdasarkan Pancasila dan Undang-Undang Dasar Negara Republik Indonesia Tahun 1945, demi terselenggaranya Negara Hukum Republik Indonesia. Pengertian kekuasaan Negara yang merdeka, di maksudkan, bahwa kekuasaan kehakiman terpisah dari kekuasaan pemerintahan dan Kekuasaan Perundang-undangan serta merdeka dari pengaruh kedua kekuasaan itu. Hal tersebut dengan jelas dapat dijumpai dalam penjelasan resmi Pasal 24 dan 25 UUD 1945.

Proses penyelesaian perkara perdata di pengadilan telah diatur dalam hukum acara per-data. Hukum acara perdata atau hukum formil perdata merupakan alat untuk menyelenggarakan hukum materiil, sehingga hukum acara itu harus digunakan sesuai dengan keperIuan hukum materiil dan hukum acara tidak boleh digunakan apabila bertentangan dengan hukum materiil. Berdasarkan pengertian tersebut, maka esensi hukum acara Perdata adalah mengatur cara bagaimana orang yang kepentingan privatnya dilanggar oleh orang lain itu dapat diselesaikan, cara bagaimana seseorang dipulihkan haknya apabila dilanggar orang lain dan cara bagaimana yang berwenang atau pe- 
ngadilan menyelesaikan atau memulihkan sengketa perdata.

Tugas pengadilan, dalam hal ini adalah hakim, yaitu untuk memeriksa, memutus, dan mengadili perkara perdata. Peradilan perdata dilakukan dengan mendasarkan pada peraturan perundang-undangan seperti HIR (Het Herzeine Indonesish Reglement), Rbg (Rechtsreglemeent Buitengewesten), Rv (Reglement op de burgerlijke recht Vordering), Undang-undang No. 20 Tahun 1947, Undang-undang No. 48 Tahun 2009 tentang Kekuasaan Kehakiman.

Hukum acara perdata, mengalami beberapa perkembangan, salah satu contohnya adalah mekanisme pengajuan tuntutan hak di luar ketentuan yang diatur di dalam Het Herzeine Indonesich Reglement Staatsblaad No. 16 tahun 1848, seperti class action, legal standing dan citizen lawsuit atau actio popularis. Berikut ini penulis paparkan karakteristik dari keempat mekanisme pengajuan tuntutan hak tersebut. ${ }^{11}$

Pertama, gugatan biasa yaitu penggugat dan tergugat merupakan subyek hukum, baik orang maupun badan hukum dengan dalil tuntutan hak berupa wanprestasi maupun perbuatan melawan hukum. Tuntutannya berupa ganti kerugian maupun melakukan atau tidak melakukan perbuatan tertentu kepada tergugat, sehingga dalam hal ini penggugat harus mempunyai perbuatan dan kerugian yang terjadi sebagai akibat perbuatan tergugat.

Kedua, class action diajukan manakala jumlah penggugatnya adalah banyak (numerous), sedangkan yang mengajukan gugatan adalah wakil kelompok, yang mewakili kepentingannya sendiri maupun anggota kelompoknya, dengan tuntutan berupa ganti kerugian. Pihak yang dapat digugat adalah seluruh subyek hukum, baik orang maupun badan hukum. ${ }^{12}$

Ketiga, gugatan LSM atau legal standing. Gugatan LSM merupakan mekanisme pengajuan gugatan oleh LSM sebagai akibat pelanggaran atau adanya perbuatan melawan hukum yang

11 Rahadi Wasi Bintoro, "Tuntutan Hak dalam Persidangan Perkara Perdata", J urnal Dinamika Hukum, Vol. 10, No. 2, Mei 2010, hlm. 156

12 Lihat juga Sulasi Rongiyati, "Class Action Sebagai Alternatif Penyelesaian Sengketa", Supremasi Hukum, Vol. 2, No. 1, J anuari 2006, , hlm. 55 dilakukan pihak lain yang merupakan kegiatan perlindungan yang dilakukan LSM tersebut sebagaimana diatur dalam anggaran dasar.

Keempat, citizen lawsuit atau actio popularis, yaitu gugatan yang diajukan oleh seorang atau lebih warga negara atas nama seluruh warga negara yang ditujukan kepada negara, dalam hal ini penyelenggara negara, sebagai akibat adanya perbuatan melawan hukum, pada umumnya berupa penelantaran hak-hak warga negara, dengan maksud agar segera dibentuk aturan hukum, sehingga hak-hak warga negara dapat terlindungi.

Mekanisme pengajuan tuntutan hak tersebut apabila dihubungkan dengan sengketa konsumen, maka terhadap sengketa konsumen dapat diselesaikan melalui pengajuan gugatan biasa, class action dan gugatan LSM/ legal standing. Pengajuan gugatan biasa dilakukan, apabila konsumen yang dirugikan terdiri dari satu atau lebih, sepanjang jumlahnya tidak terlalu banyak. Class action diajukan apabila konsumen yang dirugikan jumlahnya banyak, sedangkan gugatan LSM diajukan oleh LSM yang membidangi perlindungan konsumen, seperti Yayasan Lembaga Konsumen Indonesia (YLKI). Semua mekanisme tersebut diajukan sebagai akibat perbuatan melawan hukum yang dilakukan pelaku usaha. Hal ini mengingat, bahwa aspek per-lindungan dan keamanan merupakan hak kon-sumen di satu sisi dan kewajiban bagi pelaku usaha di sisi yang lain.

\section{Penutup}

Simpulan

Pemerintah Daerah Kabupaten Purbalingga masih bersifat pragmatis dalam usaha menggali pendapatan asli daerah dalam bidang kepariwisataan, yaitu dengan berusaha mendapatkan keuntungan sebesarnya melalui pembentukan perusahaan daerah maupun dengan penarikan retribusi. Hal ini tampak, bahwa dari sekian obyek wisata yang ada di Kab. Purbalingga hanya satu obyek wisata yang sudah ada Peraturan Daerahnya, yaitu Peraturan Daerah No. 38 tahun 2005 tentang Perusahaan Daerah Obyek Wisata Air Bojongsari jo. Peraturan Daerah Kabupaten Purbalingga No. 10 Tahun 2007 
tentang Perubahan Atas Peraturan Daerah No. 38 tahun 2005 tentang Perusahaan Daerah Obyek Wisata Air Bojongsari, yang hanya mengatur mengenai pembentukan Perusahaan Daerah Obyek Wisata Air Bojongsari. Penerapan ganti kerugian hanya diberlakukan terhadap kecelakaan fisik di obyek wisata, yang menyebabkan kerugian jiwa mau pun badan yang dilakukan melalui kerjasama Perusahaan Daerah dengan PT Jasa Raharja. Untuk kerugian non fisik/materiil, belum terdapat regulasinya.

Penyelesaian sengketa sebagai akibat dirugikannya wisatawan di obyek wisata dapat di lakukan secara damai maupun secara adversarial. Bentuk dari penyelesaian sengketa secara damai adalah negosiasi, mediasi dan konsiliasi. Penyelesaian sengketa secara adversial dapat dilakukan melalui lembaga arbitrase mau pun lembaga pengadilan. Khusus mengenai konsumen, dapat dilakukan di BPSK. Selain melalui lembaga BPSK, penyelesaian sengketa secara adversial juga dapat dilakukan melalui lembaga pengadilan, dengan mengajukan gugatan baik melalui mekanisme pengajuan gugatan biasa, class action atau gugatan LSM/legal standing. Dalil gugatan yang cenderung digunakan dalam sengketa konsumen adalah mengenai perbuatan melawan hukum.

\section{Saran}

Perlindungan konsumen seharusnya menjadi perhatian lebih, mengingat investasi bidang kepariwisataan, telah menjadi bagian pembangunan ekonomi. Merujuk pada semangat otonomi daerah, pada dasarnya usaha memberikan perlindungan hukum bagi wisatawan, pemerintah daerah dapat membentuk suatu regulasi berupa Peraturan Daerah yang secara umum mengatur mengenai perlindungan konsumen, khususnya wisatawan.

\section{Daftar Pustaka}

Bintoro, Rahadi Wasi. "Tuntutan Hak dalam Persidangan Perkara Perdata". Jurnal Dinamika Hukum, Vol. 10 No. 2, Mei 2010;
Gunawan, Endang. Kecelakaan Flying Fox, Taman Matahari. Selasa, 7 J uni 2011 19:14 wib, http:// news.oke zone.com/ read/ 2011/ 06/ 07/ 338/465628/ kecelakaanflying-fox-taman-matahari, diakses pada tanggal 11 J u-ni 2011

Hasanah, Hetty. "Perlindungan Konsumen dalam Perjan-jian Pembiayaan Konsumen atas Kendaraan Bermotor dengan Fidusia". Jurnal Unikom, Vol 3 Tahun 2004, diakses pada web site: http//jurnal. unikom.ac.id/ vol3/ perlindungan.html;

Hidayati, Maslihati Nur. "Analisis tentang Alternatif Penyelesaian Sengketa Perlindungan Konsumen: Studi tentang Efektivitas Badan Penyelesaian Sengketa Perlindungan Konsumen". Lex J urnalica Vol. 5 No. 3, Agustus 2008;

Iriansyah. "Pelaksanaan Putusan Arbitrase Asing dalam Penyelesian Sengketa Investasi di Indonesia". J urnal Hukum Respublica, Vol. 6, No. 2, Tahun 2007;

Khairandy, Ridwan. "Iklim Investasi dan Jaminan Kepastian Hukum dalam Era Otonomi Daerah". J urnal Hukum Respublica, Vol. 5, No. 2 Tahun 2006;

Khan, Suparman. "Apresiasi Hak Asasi Manusia dalam Rangka Demokratisasi di Indonesia". J urnal J urisprudentia Vol. 1 No. 1 Tahun 2001;

Rongiyati, Sulasi. "Class Action Sebagai Alternatif Penyelesaian Sengketa". Supremasi Hukum, Vol. 2, No. 1, J anuari 2006;

Sumiyati, Sri dan Rini Fatmasari. "Peranan Yayasan Lembaga Konsumen dalam Memberikan Perlindungan Konsumen". J urnal Pena Wiyata. Jurdik dan Hum. No. 9 Tahun V, September 2006;

Wijoyo, Hadion. "Problematika Hukum di Bidang Investasi dalam Era Otonomi Daerah". Jurnal Hukum Respublica, Vol. 5, No. 2, Tahun 2006;

Wijoyo, Hadion. "Problematika Hukum di Bidang Investasi dalam Era Otonomi Daerah". Jurnal Hukum Respublica, Vol. 5 No. 2, Tahun 2006;

Yoety, Oka A. 2009. Industri Pariwisata dan Peluang Kesempatan Kerja. Jakarta: PT Pertja. 